\title{
Russia and Germany in the Life of the American Diplomat George Frost Kennan (Toward His $110^{\text {th }}$ Birthday)
}

\author{
Oleg V. Bodrov ${ }^{1}$, Larisa L. Norden ${ }^{1} \&$ Rustem N. Chanyshev ${ }^{1}$ \\ ${ }^{1}$ Kazan (Volga Region) Federal University, Kazan, Russia \\ Correspondence: Chanyshev Rustem Narimovich, Kazan (Volga Region) Federal University, 420008, Russia, \\ Kazan, Kremlyovskaya Street, 18, Russia. E-mail: spacecowboy85@bk.ru
}

Received: June 15, 2015 Accepted: June 24, 2015 Online Published: June 30, 2015

doi:10.5539/jsd.v8n7p1 URL: http://dx.doi.org/10.5539/jsd.v8n7p1

\begin{abstract}
A well-known American diplomat and historian George Frost Kennan's (1904-2005) activities studying is still a live issue today and brings us to a different regarding of the key aspects of international relations in the XXth century. Kennan is one of the founders of ideas of "political realism" in the history and theory of international relations and "power equation" in geopolitics as well as the author of the famous "doctrine of containment" which had provided the basis for the USA foreign policy for decades. In this regard the article is aimed at the complex evaluating of the role of Germany and Russia in the life of the American diplomat George Frost Kennan. While working on this article we used a historical-comparative approach enabling comparison of different events and different points of view as well as his own ones during different periods of his life. When studying the role of Russia in Kennan's life, it should be noted that with it his very first and bright diplomatic appointments are connected and they allowed exploring the Russian political system, developing a passion for the Russian culture, learning the Russian people, whom he had admired through his life. "Russian issue" had always been the cornerstone of not only Kennan's diplomatic, but also academic and social-political career. The German issue had also been widely regarded in the work of the diplomat.
\end{abstract}

Keywords: "containment doctrine", international relations, Soviet-American relationships, diplomacy, foreign policy

\section{Introduction}

Today, a lot is said and written about the era of the "cold war", antagonistic contradictions between the two world systems, complex relationship problems of relations of different states in this era are touched upon. All this only shows that even today not everything is fully understood in this regard and the issue of the complex relationships is not so clear as it might seem first. The reasons for the ideological and geopolitical confrontation between two irreconcilable systems, their rivalry with each other, and most importantly - the outcome of this confrontation, that is what makes it interesting for researchers throughout the world. But the most important thing is what impact these events have on the world today, on the current status of Russia on the international level, on its image in the world and its relations with other states.

When it comes to the "cold war", its premises, causes and, of course, the outcome we begin to talk about certain personalities that determined the direction and course of international politics in this era. There, among all the others, stands out the identity of the American diplomat George Kennan Frost (1904-2005). His outlook for a long had defined the US policy toward the Soviet Union. The name of this politician comes out from time to time when historians try to pay tribute to the person, who in fact, discovered the Soviet Union for the Western world, showed all its inconsistencies and internal contradictions, brought the history and culture of the Soviet people to his compatriots.

In the biography of George Frost Kennan, a well-known diplomat and historian, a lot of things are connected with Russia, "the Russian issue" (Malkov, 2009). Russia had always been a country that Kennan admired. Russia attracted him, he had the opportunity to contemplate it from the inside, carrying out his diplomatic service for a long period.

It is obvious that George Kennan was an outspoken opponent of the regime and hated the Soviet system, the system that today is idealized by a significant part of the Russian population. Kennan, of course, was the 
representative and the tool of those forces of the world order, which did their best for the Soviet socialist system to fail as a possible future system. In this regard, we should not overidealize his "good" attitude to Russia. What is more important is the fact that Kennan was the first who pointed to the fundamental disadvantages of the socialism, including "a tendency to self-extinction" (Malkov, 2009) of totalitarian regimes, and "the spiritual gap between those who govern and those who are governed» (Kennan, 1989).

A lot of personal, career and creative moments in Kennan's life are associated with Germany. As for his views, origin and behavior Kennan "was more a northerner and European, than a Scotsman or an Englishman ..." (Lukacs, 2007).

Deeply idealizing and admiring the traditional culture of both countries, Kennan was quite critical of regimes that prevailed in them during the crucial for the whole world 1930s. One of the biggest mistakes of all specialists on the Soviet Union at that time was a tragic underestimation of the German threat. "Nazism in his eyes - the historian V. L. Malkov says- in comparison with Bolshevism seemed at least more civilized..."(Malkov, 2009). Germany and Russia outline the range of basic scientific interests of Kennan-historian and are the key states in the career of the diplomat.

\section{Methodological Framework}

The reference books regarding aspects of life and work of George Kennan considered in the article, can also be divided into two sections: foreign and Russian.

Foreign reference books, in turn, are divided into two groups:

The first group - special works of Kennan's main biographers. This group contains fundamental works by foreign authors that influenced the study of Kennan's life: Congdon L. George Kennan: a Writing Life (2008), Harper J. L American Visions of Europe. Franklin D. Roosevelt, George F.Kennan and Dean G. Acheson (1997); Hixson W. L. George F. Kennan Cold War Iconoclast (1997); Lukacs J. George Kennan: a Study of Character (2007).

The second group - the works of George Frost Kennan himself relating to the period, among them the legendary "Long Telegram", "Roots of Soviet Conduct," "America and the Russian future", as well as diaries and personal notes.

Using Russian reference books, we primarily rely on the works of leading national experts on the "Cold War", among which, for example, we can distinguish the landmark book of the famous Russian Americanist V.L. Malkov "Russia and the United States in the twentieth century: essays on the history of international relations and diplomacy in the socio-cultural context" (2009). Of great importance are the articles on George Kennan's biography itself: V. O. Pechatnov "Man for all time" (2007), V. L. Malkov "Unknown Kennan: notes on morphology of the diplomat" (2003).

\section{Results}

\section{1 "Russian issue" in the life of George Frost Kennan}

In the biography of George Frost Kennan, the famous politician, diplomat and historian, much is connected with Russia, "Russian issue" (Malkov, 2009). Russia had always been a country that Kennan admired. Russia attracted him, he had the opportunity to contemplate it from the inside, carrying out his diplomatic service for a long period covering the 30s, 40s and 50s years of the XXth century. Kennan's interest in Russia arose mainly due to the legendary George Kennan senior, a well-known publicist, expert on Russia who studied hard life of people during a Siberian penal servitude in the XIX century, to whom the diplomat was a grandnephew. This affinity can largely explain Kennan 's interest in Russian history and culture, and, in consequence, a brilliant career in the field of Soviet-American relations.

Kennan, as a political analyst first drew attention to himself as a specialist on the Soviet Union in connection with a telegram of 8000 words, which he sent to the State Department, as a member of the American Embassy in Moscow. This document, prepared in February 1946, entered the history of diplomacy under the title of "a long telegram". "A long telegram" is a complex historical source, analytical document, written at the height of Kennan's discontent with understanding of the USSR by American politicians. The first part Kennan explains main principles of the postwar Soviet ideology. Kennan comes to the conclusion that the Soviet Union aims at strengthening its power as opposed to the Western powers, at heating up conflict between the capitalist powers, the struggle with the Socialists and Social Democrats in the West, trying to exercise pressure on the "capitalist governments in areas consistent with the Soviet interests "(Kennan, 1990) with the help of democratically-progressive elements. The second section, entitled "History of the philosophy" Kennan writes 
that Marxism "is not an inherent philosophy of the Russian people (Kennan, 1990), as they are friendly to everything external by their nature. The Russian society is imposed dogmas absolutely not typical to it. Kennan comes to the conclusion that the Soviet government is primarily engaged in self-deception and is not willing to look at things objectively. In the third part Kennan reports on the official plane of the program of the Soviet Union. Here he drew attention to the fact that domestic policy is entirely devoted to the build of strength; attempts are being made, if possible, "to officially expand the boundaries of the Soviet power"; The Soviet Union will take part in the activities of international organizations for their own purposes; there will be attempts to reduce the influence of capitalist countries towards the colonial and backward dependent peoples; the USSR aims at autarky in international economic issues; there will be created the illusion of cultural relations and "the right course" regarding some certain foreign governments (Kennan, 1990).

In the fourth section Kennan is focused on informal level of Soviet foreign policy. Here he says about clandestine activities of the Comintern, the desire of the Soviets to influence through the range of national associations and bodies, international organizations, Russian and Oriental Orthodox churches and others.

In the last fifth part of the report it comes to practical conclusions, which should be reached by the USA.

"Kennan was different from all the other experts - said Henry Kissinger - by the fact that he described the mechanism with the help of which, sooner or later, as a result of some military action, the Soviet system will be fundamentally transformed" (Kissinger, 1997). Kennan was withdrawn from Moscow to the United States and was assigned to a very significant position in the National War College. He later became the head of the department of foreign policy planning at the US State Department. "Long Telegram" was the document that had defined the working out the USA foreign policy toward the Soviet Union for years to come..

In July, 1947 in the journal "Mezhdunarodnye dela" ("Foreign Affairs") there was published an article under the title of "Istoky sovetskogo povedenyia" ("The Sources of Soviet Conduct"). Here, the contents of the "long telegram" get more widespread.

However, as head of the department of Foreign Policy Planning of the State Department, Kennan did not want to sign his own name and chose the pseudonym "X".

That was the article, where Kennan expounded his idea of the legendary later "policy of containment".

What were the main provisions of Kennan's article?

This complete historical study of the analytical type and instructive nature is divided by Kennan into three sections. In the first part of the article, Kennan offers engrossing into the origin of the ideology of the Soviet Communist movement. He notes that "the Marxist ideology in the version that has been spread among the Russian Communists is all the time being modified." Kennan says that "for fifty years before the revolution," the future revolutionaries, offended and holding a grudge against the czarism, were focused on the future "inevitable overthrow of hostile power, which, in their opinion, had to be preceding the construction of" the ideal society (Kennan, 2005). In other words, these people did not have any constructive program and methods of implementation of reforms.

According to Kennan, the established regime in the country could no longer exist without the coercion of the people, i.e. without the dictatorship, and the thesis of the permanent threat posed from outside actually justified the need for the "organs of suppression" (Kennan, 2005).

In the second part of the article Kennan examines the nature of the ideology of the regime. Here a few concepts come to the fore.

"The first concept - says Kennan, - concerns immanent antagonism between capitalism and socialism. We have already seen to which extend it interwoven with the foundations of Soviet power. It has a profound impact on the behavior of Russia as a member of the international community. It means that Moscow will never truly recognize common goals of the Soviet Union and the countries it considers capitalist. Moscow is likely to believe that the goals of the capitalist world are antagonistic to the Soviet regime and, consequently, to the interests of the peoples under its control"(Kennan, 2005). According to Kennan this is the main problem of relations with the USSR.

The second concept is a "thesis about the infallibility of the Kremlin. The Soviet concept of power not allowing any organizational centre outside the party itself requires that in the theory the party leadership should remain the only source of truth. For if the truth was discovered somewhere else, it could serve as a justification for its existence in its organized activities. But this is what the Kremlin can not tolerate and will not tolerate." The very this principle of infallibility is the basis for discipline in the party. 
The third important concept in conjunction with the first two, defining "the model of behavior of the entire Soviet apparatus of power" is that "the management may tackle any thesis for tactical purposes which it considers useful to the case at the moment, and require faithful and unconditional consent of all the members of the movement as a whole. This means that the truth is not immutable, but is actually created by the Soviet leaders themselves for all intents and purposes" (Kennan, 2005).

In the final third part of the article the author prepares the reader to further relations with the Soviet state. He calls to not overestimate the opinion of Soviet politicians that the truth is on their side.

"However, - said Kennan, - large uncertainty loomed over the political life of the Soviet Union, the same uncertainty that is associated with the transition of power from one person to another or from one group of people to another." He ties this problem primarily with the personality of Stalin and ossified "political life" (Kennan, 2005).

Kennan claims that the antagonism between the different generations will grow sooner or later. He can't imagine the way the effective rejuvenation of the political elite will be carried out without any changes in regime itself. Here Kennan defines instability and fragility of the regime.

Having taken the provisions proposed in the article, Kennan offers to carry out "a resolute policy of containment to oppose to the Russians indomitable force in any part of the Earth where they will try to encroach on the interests of peace and stability" (Kennan, 2005). One is struck by the vagueness of such formulations. It is for this breadth of interpretation of ways by which "deterrence" should be carried out Kennan at the time incurred the wave of acute discontent of political theorists. However, if to consider the "containment" only a thesis according to Kennan, not a full-fledged political vector, the value of given provisions and recommendations in the article is absolutely clear.

Thus, in his article, Kennan gave a historical retrospective of the development of the communist ideology in Russia, the essence and the main problems faced by the Soviet regime, as well as a recipe for future relations with the USSR. As in the "long telegram" Kennan strongly encourages thinking about the problems associated with the Soviet Union, but we can't see that hint of open, irrespective military confrontation.

Kennan believed that it will be right to identify the main areas for implementing a policy of "containment." They were Britain, Japan and the Rhineland in the then West Germany. He recommended the US leadership to adhere to the principle of non-use of nuclear weapons first, opposed the deployment of nuclear missiles in Western Europe. Subsequently, calling for arms reduction at the end of the life he had become a champion of the complete elimination of nuclear weapons

The basic principle of the policy of "containment" was the desire not to make unilateral concessions to the Kremlin and oppose the Stalin's administration attempts to expand their sphere of influence. However, the most hotly his recommendations were accepted by the representatives of the right wing of the American society - the "hawks." The task to counteract by military means the geopolitical threat posed by the Soviet Union was on the first place in the strategy of the United States. That is why during his subsequent life Kennan refused to recognize himself as the actual author of the "Truman Doctrine".

Kennan's views on Russia and the Soviet Union were not unambiguous. His hostility to the USSR, he explains only as hostility to the regime. The views of the diplomat on Soviet foreign policy evolve from the fear of open aggression by the Soviet Union to the statement of the fact that no wars and world revolutions were needed to the Soviet regime.

The main task of the West, he thought was "a long, patient but firm and vigilant containment of Russian expansive tendencies," which eventually would lead to "the gradual softening or collapse" of the Soviet system (Pechatnov, 2007).

"In the national character of the Russian people - wrote Kennan, - there are many positive features, but the present situation in Russia urgently requires a new form of government that would allow these positive features emerge ... give them the opportunity to resolve their internal problems in their own way" (Kennan , 2007). Russia to Kennan was, above all, a country with its culture, history and people, and the Soviet Union was associated with the regime, having broken traditions.

\subsection{Germany in the life of George Frost Kennan}

Germany, like the rest of Western Europe, attracted educated Kennan by their classic conservative culture. He felt his spiritual affiliation to the Old World, intellectually identifying himself as the noble top of European society. 
The visit with his family to Germany played a special role in Kennan's life. "Thanks to his father - said Kennan's biographer John Harper - German became his first foreign language, and Germany became the first foreign country he learned" (Harper, 1997).

Many years later Kennan, as a future specialist on Soviet Russia, with which it was supposed to establish diplomatic relations soon, got the opportunity to go through a special program to study Russian language, history, economy and culture in the University of Berlin. "I became a graduate student - wrote Kennan - of the so-called Eastern workshop at Berlin University. Originally created by Bismark for training diplomats working in the East, this one-of-a-kind of departments by that time had become the center for studies of Oriental cultures. The Russian department issued diplomas of interpreters to its graduates. However, the examinations should be taken not only on the language, but also on the history of the state and law, and economical geography of Russia"(Harper, 1997).

In 1933-1936, Kennan worked much in the American embassy in Moscow, and then because of disagreements with the second Ambassador Joseph Davies he was sent home, and in late 1930 he was back in Germany.

September 12, 1939, Kennan was transferred to Berlin as the second secretary of the embassy. He entered upon duties four days before Pearl Harbour events (December 7, 1941). But immediately after the declaration of war on the USA by Germany on December, 10 Kennan was deprived of "a truly rare opportunity for him - to give an independent assessment of the subject, in which he felt himself an expert of high class. Along with the other 130 American diplomats, he was interned by Gestapo to Bad Nauhem city, near Frankfurt, where he had spent his time as a prisoner for five months. The land, with which he mentally merged and which personified in his opinion the best in the cultural heritage of Europe, its supporting firmament, became a place of humiliating imprisonment. The spiritual and intellectual self-isolation of the diplomat and philosopher only intensified with grief of lost loyalty to German history, disappointment in its inner legality. Caught in the grip of adventurers Hitler and his henchmen - Germany lost the right to claim a consolidating role in Europe" (Malkov, 2009). During five months of imprisonment near Frankfurt Kennan became a moral "leader" and "teacher" of all prisoners (Lukacs, 2007). Soon all of them were exchanged for a similar group of Germans in Lisbon.

In the early 1950s, Kennan received the long-awaited appointment as ambassador to the USSR, but in 1952 "he was declared persona non grata by the Soviet government" (Malkov, 2009). In fact, Kennan was expelled for entirely inappropriate, especially at that time, comparison of the Nazi regime with the Stalin regime in public. Making such statements, being the official representative of the USA in the USSR, and even in Berlin, was extremely reckless act on the part of a diplomat.

A few years later, before the construction of the wall, Kennan visited Berlin, and in particular its eastern part. East Berlin was in ruins and a bombed out in strong contrast was bustling and thriving West Berlin (Congdon, 2008).

Since the mid-1950s, Kennan actually left his civil service and was closely engaged in research and teaching at Princeton University. In his writings, he had focused on the problems of Soviet-American relations, the US foreign policy and the history of Russia, the issue of the reunification of Germany also held a special place in his work. In the late 1950s, Kennan had the opportunity to travel on the European continent. He was in England, Denmark and Germany in the framework of public speeches, lectures and conferences. In September 1959, traveling in Hamburg, the city which played an important role in his life, Kennan noted the sad fact for himself a "Europe of his youth had no longer existed." Even before the construction of the wall Kennan visited Berlin and the eastern part in particular. "East Berlin was in ruins and was bombed out in strong contrast with bustling and thriving West Berlin» (Congdon, 2008).

A number of works of Kennan had been connected with the German problems.

In 1957, Kennan read on the BBC radio a few lectures on topical international issues.

Walter Hixson, the biographer of the diplomat, said: "Kennan challenged the fundamental provisions that lay at the root of the post-war international system.... Having sounded at the night when NATO decided to deploy nuclear missiles in Western Europe, the lectures had twinkled by comments in the West and calls to consider the consensus of "containment" that Kennan himself voiced a decade earlier. As before in 1948, the leaders-allies rejected Kennan's call for the unification of Germany, the liberation of the great power and the creation of nuclear weapon-free zone in Europe. Rejection of his proposals reflected in the focusing of thoughts on a possible Soviet invasion, along with the perception that the Cold War provided a stable international order (Hixon, 1989).

In the following lectures Kennan mentioned the unification of Germany and the withdrawal of troops, which 
largely would withdraw the stress. Germany would never have become a member of NATO, on turning to an independent border state, which would ensure peace and stability in Central Europe.

In the united in common collection of lectures "Russia and the West under Lenin and Stalin" (1961) Kennan strongly warns the US ruling circles against giving nuclear weapons to FRG, because "such a move can have fatal consequences.., its probably would have caused serious aggravation of existing military strain in Europe ... After that we once and for all would lose the hope that the Russians will leave Central and Eastern Europe, for elementary military caution will dictate them not to do it »(Kennan, 1961).

Four years later Kennan, "speaking on February 18, 1965 in New York at the international symposium on peace and mutual understanding sharply criticized the US policy on the German issue and, in general, on European issues. He pointed out that this policy had increased the danger of uncertainty associated with the situation in Berlin and that this policy had "given nothing" vital. Kennan saw that the failure was caused by "internal contradictions". He wrote: "The military objectives, in particular, the inclusion of united Germany as an important component in the western defense system, based primarily on nuclear weapons, are obviously in contradiction with the main political purpose: to force the Soviet Union to leave Central Europe, for no Russian government, whether it's communist or any other, can not afford itself to leave conceding to such a demand."

Kennan proposed "developing a common Western policy, not so much related to inner political considerations, which put pressure on the West Germany government. He believed that we should not give in the future to West Germany a "full opportunity to rearm," especially by nuclear weapon, that "we should give greater assurance to Poland and other countries on the issue of the eastern borders of Germany as one of the constituent elements of a possible settlement of the difference between the East and the West. " Finally, Kennan recommended "coming to terms with at least a temporary existence of independent East Germany political body" (Appatov, 1966).

In 1977 Kennan wrote a book called "Looming threat". He emphasized that FRG was the main pillar of the US in Europe especially because in this country the population is less than in any other countries was inclined to anti-American sentiments. Kennan urged the United States to maintain the morale of the British, as the closest of allies, and to be generous towards small countries of Western Europe.

Germany took a special place in the life of George Kennan. It affected several important aspects of life Kennan's life.

Talking about a personal aspect we can remember the love of all the European and German, which was raised in son by his father, the first European impressions were connected with Germany, and German was the foreign language which, like Russian, Kennan mastered perfectly. In Germany, Kennan received his second degree, more over, when living in Berlin Kennan met his future wife, with whom his life was long and happy.

As for the career of Kennan as a diplomat connected with Germany, much could be said. It should be noted that due to studying in the University of Berlin and serving in Germany Kennan received the best education and became a part of the US diplomatic elite.

The German issue, particularly in the context of the problems of the bipolar world during the "Cold War" had found a significant reflection in the works of Kennan.

\section{Discussions}

Germany and Russia took a special place in the life of George Frost Kennan.

Love to all European, and especially German, which Kennan got from his father, as well as the first European experience are connected with Germany. German was the foreign language, which, like Russian, Kennan mastered perfectly. In Germany, Kennan received an excellent education, met his future wife, at the same time experienced a profound disappointment associated with the Nazis discrediting the traditional values of the German people.

The first diplomatic assignments of Kennan are connected with Russia and it provided a tremendous opportunity to explore the Soviet political system, to get acquainted with Russian history, culture and the people, whom he had admired all his life. In addition, it was the "Russian issue" which led Kennan in his career as a statesman. The German issue, particularly in the context of the problems of the bipolar world in the period of "cold war", also found a significant reflection in the works of the diplomat.

Through his activities related to Russia, Kennan acquired the status of an authoritative historian and politician. His analytical skills and talent in predicting the international relations are largely manifested in such legendary documents as the "Long Telegram", "Article X" and "America and the Russian future." In addition, George Frost Kennan had established himself as a rigorous historian of pre-revolutionary Russia, as well as a brilliant 


\section{Sovietologist.}

\section{Conclusion}

In the world politics there are not many people who are able to think so globally, that it could determine the development of entire political industries and institutions and give directions for the state structures. But there were much less personalities, who represented the entire era and influenced the most significant events in world history.

These people in the world politics of the twentieth century were not so numerous. They, like an experienced sculptor, molded whole concepts of the political development of a country, region and even a part of the world, whereby they were able to influence the development of the whole world. They, being a kind of ideologists of the time in which they lived determined the entire direction of movement of world politics in the future.

Among these personalities that influenced the world in the twentieth century, stood out the figure of George Kennan - a distinguished statesman, experienced diplomat and outstanding historian.

Kennan's heritage value as a historian of foreign policy, diplomat and politician can hardly be overestimated. In the twenty-first century, it is necessary to carefully study and comprehend and use this heritage.

Kennan brought an invaluable contribution to the history of Soviet-American relations. His works are considered classic for the study of American history and diplomacy, especially the US-Soviet relations.

George Kennan, was directly involved in the work of the US diplomatic corps in Moscow. He was one of the leading members of the embassy, who constantly expanded his knowledge about the country in which he worked. Kennan worked in the USSR in one of the crucial periods of Soviet-American relations in the history of the twentieth century.

Kennan was involved in developing a number of important political events. Among them: the "Marshall Plan", the development of a number of foreign policy recommendations and guidelines, among which NSC 20/1 was dominating and the plan "A". Kennan was involved in the development of covert operations in Eastern Europe with the aim of non-violent overthrow of the communist regime, he worked in the project "Solarium" under President Dwight D. Eisenhower on the development of Soviet-American relations.

It is necessary to clarify that Kennan was, first of all, an analyst and foreign policy planner. Diplomacy itself was not dominating in his life. He did not come into diplomacy intentionally, it was after graduating from Princeton at the time, when he had no idea where to apply his skills. Therefore, he was not a career diplomat in the truest sense of the word, he often sacrificed his career to his convictions. He knew how to solve the problems set by his senior colleagues as well as to solve administrative issues. The only large-scale event in his diplomatic career was the "Long Telegram," which, in turn, was more the result of his work as an analyst and specialist on the USSR, not a diplomat. He failed, and probably did not want to show his diplomatic skills when he was an ambassador in 1952 to Moscow. Therefore, to link his name only with diplomacy, or even with "containment" would be a simplification and underestimating him as a historian, teacher, publicist and public figure.

George Frost Kennan's ideas have to find their followers not only because they belong to one of the famous diplomats and politicians in the history of the XX century, but also because they compacted the experience and the results of long-term thinking of a man who witnessed or directly participated in many major events of the twentieth century.

\section{Acknowledgments}

The work is performed according to the Russian Government Program of Competitive Growth of Kazan Federal University.

\section{References}

Appatov, S. I. (1966). Amerikanskaya burzhuaznaya istoriografiya germanskoy problemy. Moskva.

Congdon, L. (2008). George Kennan: a Writing Life. Wilmington: ISI Books.

Harper, J. L. (1997). American Visions of Europe. Franklin D.Roosevelt, George F.Kennan, and Dean G.Acheson. New York: Cambridge University Press.

Hixson, W. L. (1997). George F.Kennan Cold War Iconoclast. New York: Columbia academy Press.

Kennan, G (2005). Istoki sovetskogo povedeniya. Istoriya SSHA. Hrestomatiya: posobie dlya vuzov. Moskva.

Kennan, G. (1990). 861.00 / 2-2246: Telegramma. Mezhdunarodnaya zhizn, 11, 140-148.

Kennan, G. F. (1989). Sketches from a Life. New York: W.W. Norton \& Company. 
Kennan, G. F. (2007.) America and the Russian Future. 200 let rossiysko-amerikanskih otnosheniy. Moskva.

Kissinzher, G. (1997). Diplomatiya. Moskva.

Lukacs, J. (2007). George Kennan: a Study of Character. New Haven and London: Yale University Press.

Malkov, V. L. (2009). Rossiya I SSHA v XX veke: ocherki istorii mezhdunarodnyh otnosheniy $i$ diplomatii $v$ sotsyokulturnom kontekste. Moskva.

Pechatnov, V. O. (2007). Chelovek na se vremena (pamiati Dzhorzha Kennana). 200 let rossiysko-amerikanskih otnosheniy. Moskva.

\section{Copyrights}

Copyright for this article is retained by the author(s), with first publication rights granted to the journal.

This is an open-access article distributed under the terms and conditions of the Creative Commons Attribution license (http://creativecommons.org/licenses/by/3.0/). 